\title{
Dukungan Kelembagaan Masyarakat dalam Pembelajaran Petani untuk Pengelolaan Hutan Rakyat Lestari di Kab. Gunung Kidul, Provinsi Daerah Istimewa Yogyakarta dan Kab. Wonogiri, Provinsi Jawa Tengah
}

\author{
Local Institutions Support in Farmers's Learning for Implementing \\ Sustainable Private Forest Management in Gunung Kidul District, \\ DI Yogyakarta Province and Wonogiri District in Central Java Province
}

\author{
Yumi $^{1}$, Sumardjo ${ }^{2}$, Darwis S. Gani ${ }^{2}$, Basita G. Sugihen ${ }^{2}$ \\ ${ }^{1}$ Kementerian Kehutanan, Jakarta \\ ${ }^{2}$ Departemen Sains Komunikasi dan Pengembangan Masyarakat \\ Fakultas Ekologi Manusia Institut Pertanian Bogor
}

\begin{abstract}
Forest Management is facing the challenge of implementing the sustainable forest management which includes private forest. Successfully gained the Ecolabel Certificate, some private forest management units in Central Java and Yogyakarta's districts prove that the small units run by farmers are able to implement the sustainable forest management. The farmers'success in implementing the sustainable forest management must have been gained through learning process. How the learning process was and what local institutions influencing the farmers' learning process of the sustainable private forest management were, were the research questions of this study. The study used explanatory survey method on 200 farmers in Gunung Kidul and Wonogiri. Data collection was conducted from December 2009 to February 2010. The data were analyzed by using descriptive technique and Structural Equations Model (SEM). The conclusions are: (1) informal local institutions have stronger influence in farmers' learning than formal institution; (2) local institution aspects : norm, objection of organisation, leadership are potential aspects in influencing farmers' learning intensity; (3) farmers' learning intensity can be improved by strengthening informal local institutions and improving farmers' capacities in organisation management.
\end{abstract}

Keyword: Sustainable private forest management, private forest, farmers' learning process, local institutions, social capital

Abstrak

Pengelolaan hutan, termasuk pengelolan hutan oleh masyarakat menghadapi tantangan dalam mewujudkan pengelolaan hutan secara berkelanjutan (lestari). Keberhasilan petani dalam pengelolaan Hutan Rakyat di Kabupaten Gunung Kidul dan Wonogiri sampai memperoleh Sertifikat Ekolabel membuktikan bahwa masyarakat dapat mengelola hutan secara lestari. Keberhasilan tersebut merupakan hasil dari suatu proses belajar. Bagaimana pembelajaran masyarakat dan kelembagaan lokal mana yang mempengaruhi pembelajaran petani merupakan pertanyaan yang perlu dijawab dalam penelitian ini. Penelitian ini menggunakan metode survey dengan 200 responden petani Hutan Rakyat sertifikasi di Kabupaten Gunung Kidul dan Wonogiri. Pengambilan data dilakukan pada bulan Desember 2009 sampai dengan Februari 2010. Analisa data dilakukan menggunakan statistik deskriptif dan inferensial, Structural Equations Model (SEM). Hasil penelitian menunjukkan bahwa: (1) kelembagaan masyarakat yang informal memiliki pengaruh yang lebih besar pada intensitas belajar petani dibandingkan kelembagaan formal, yang dibentuk dengan tujuan memenuhi persyaratan sertifikasi semata; (2) norma, tujuan organisasi dan kepemimpinan merupakan aspek yang berpengaruh terhadap intensitas belajar petani; (3) intensitas belajar petani dapat ditingkatkan dengan memperkuat kelembagaan informal dan meningkatkan kapasitas petani dalam pengelolaan kelompok/organisasi.

Kata kunci: Pengelolaan hutan berkelanjutan/lestari, hutan rakyat, proses belajar petani, kelembagaan lokal, kapital sosial

\section{Pendahuluan}

Kerusakan hutan yang semakin parah, baik akibat illegal logging, kebakaran hutan dan lahan, ketimpangan antara kapasitas terpasang pada industri kehutanan dengan kemampuan penyediaan bahan baku kayu bulat merupakan sebagian permasalahan serius dalam pembangunan kehutanan. Pada sisi lain kemiskinan penduduk yang tinggal di sekitar hutan juga merupakan masalah penting yang memerlukan perhatian khusus dalam pembangunan kehutanan. Hutan rakyat merupakan salah satu alternatif penting untuk menjawab permasalahan tersebut. Hasil-hasil penelitian yang dilakukan oleh Badan Penelitian dan Pengembangan Kehutanan (Badan Litbang) Kementerian Kehutanan, Forum Kehutanan Masyarakat (Fakultas Kehutanan, Institut Pertanian Bogor), Pusat Kajian Hutan Rakyat (PKHR), Fakultas Kehutanan Universitas Gadjah Mada 
menunjukkan bahwa hutan rakyat telah terbukti berperan dalam pembangunan kehutanan, khususnya dalam segi ekonomi, ekologi dan sosial. Darusman (1995) menegaskan bahwa bahwa hutan rakyat dan industri pengolahan hasilnya merupakan pilihan teknologi budidaya dan industri yang tepat guna bagi wilayahwilayah berlahan marjinal dengan kondisi sosio budaya tradisional.

Berdasarkan hasil-hasil penelitian yang dikaji oleh Badan Litbang Kehutanan dari beberapa lokasi hutan rakyat, permasalahan-permasalahan yang mengakibatkan terhambatnya perkembangan hutan rakyat dikelompokan ke dalam empat sub sistem, yaitu: produksi, pengolahan hasil, pemasaran, kelembagaan dan kebijakan serta peraturan perundangan (Mindawati, Widiarti, Rustaman, 2006). Permasalahan pada sub sistem kelembagaan, kebijakan dan peraturan perundangan adalah: (a) sumber daya manusia masih rendah, intervensi pemerintah dalam pembentukan kelompok sifatnya top down dan pembinaan tidak berkelanjutan atau bersifat keproyekan; (b) kebijakan pembangunan kehutanan masih mengacu pada penanaman dan belum dirancang secara terpadu dengan komoditi yang lain agar pemanfaatan lahan lebih optimal; (c) kurang komunikasi baik antar multipihak.

Tantangan lain yang juga dihadapi dalam pengembangan hutan rakyat ialah berkaitan dengan adanya isu global warming dan ekolabel, yang mensyaratkan kayu-kayu yang telh bersertifikat sebagai ketentuan untuk dapat masuk pasar kayu internasional. Unitmanajemen pengelolaan hutan rakyat di Kabupaten Gunung Kidul, Provinsi Daerah Istimewa Yogyakarta dan Kabupaten Wonogiri, Provinsi Jawa Tengah, yang dikelola oleh masyarakat setempat telah membuktikan bahwa rakyat telah mampu mengelola hutan secara lestari dan mendapatkan sertifikat Ekolabel.

Keberhasilan tersebut melewati suatu proses belajar, dan juga proses belajar masyarakat tersebut yang pada dasarnya merupakan kegiatan penyuluhan. Keberhasilan masyarakat tersebut sangat terkait dengan peran berbagai kelembagaan masyarakat. Kelembagaan apa saja yang berperan dan bagaimana kelembagaan masyarakat tersebut berperan dalam pembelajaran masyarakat menjadi pertanyaan yang perlu dijawab dalam penelitian ini. Dengan demikian tujuan penelitian adalah: 1) menganalisis kelembagaan masyarakat apa saja yang mendukung pembelajaran petani dalam pengelolaan hutan rakyat lestari; 2) bagaimana pengaruh kelembagaan masyarakat terhadap intensitas belajar petani; dan 3) bagaimana meningkatkan pengaruh kelembagaan masyarakat terhadap intensitas belajar petani dalam pengelolaan hutan rakyat lestari.

Klausmeier dan Gooodwin (1971), Soemanto (2006), Suryabrata(2006) mengemukakan faktor-faktor yang mempengaruhi proses belajar yang secara umum terbagi dua bagian besar yaitu faktor eksternal dan faktor internal. Faktor eksternal yang mempengaruhi proses belajar antara lain adalah: kompetensi pengajar; pendekatan atau metode pengajaran yang digunakan; lingkungan sosial dimana pembelajar tinggal atau bermasyarakat; dan kelembagaan yang memfasilitasi proses belajar. Tulisan ini lebih difokuskan pada kajian lingkungan sosial yang memfasilitasi proses belajar petani Hutan Rakyat Lestari.

Belajar bagi orang dewasa mengarah pada proses pemenuhan kebutuhan belajar dan pencapaian tujuan belajar. Orang dewasa merasakan adanya kebutuhan untuk belajar dan melihat tujuan pribadinya akan tercapai melalui belajar. Proses belajar akan terpusatkan pada pengalaman sendiri melalui interaksi antara dirinya dengan lingkungannya. Kualitas belajar akan dipengaruhi oleh kuantitas dan kualitas interaksi dengan lingkungannya. Dengan demikian seni membelajarkan orang dewasa merupakan upaya mengelola lingkungan dan interaksinya dengan peserta didik melalui proses pembelajaran (Sudjana, 2000). Flanders (1969), diacu dalam Klausmeier dan Goodwin (1971), menyebutkan bahwa dalam proses belajar, kualitas interaksi antara guru dan murid, murid dan murid, guru dan guru serta guru dan pegawai mempengaruhi hasil belajar. Interaksi guru dan murid sangat dipengaruhi oleh hubungan interpersonal, komunikasi verbal dan non verbal. Interaksi guru dan murid terjadi jika ada komunikasi dua arah dan seimbang. Demikian interaksi sesama murid, akan mendukung pencapaian tujuan kelompok. Kekohesivan kelompok sangat berperan dalam mendukung proses belajar.

Pretty (1995) menyebutkan bahwa kesuksesan sistem pertanian berkelanjutan tidak hanya bergantung pada motivasi, ketrampilan dan pengetahuan individu petani, tetapi pada tindakan yang dilakukan oleh kelompok masyarakat lokal secara keseluruhan. Sejalan dengan itu Ostrom (1990), diacu dalam Pretty (1995), menegaskan bahwa kegagalan untuk mencapai pemanfaatan sumberdaya alam secara berkelanjutan disebabkan oleh fokus pengelolaan tanpa mempertimbangkan kerangka kelembagaan di lokasi tersebut. Hasil studi Bank Dunia terhadap proyek pembangunan pertanian selama ini menunjukkan 
bahwa keberhasilan proyek secara berkelanjutan terjadi bila memberikan perhatian pada pembangunan kelembagaan dan partisipasi masyarakat (Cernea, 1988).

Uphoff (1992), diacu dalam Pretty (1995), menggunakan istilah "lokal" untuk institusi atau kelembagaan masyarakat, karenamemilikikarakteristik khusus. Institusi atau kelembagaan lokal dalam hal ini berarti menjadi dasar untuk kegiatan kolektif, untuk membentuk konsensus, untuk menjalankan peran dan tanggung jawab koordinasi, dan untuk mengumpulkan, menganalisa dan mengevaluasi informasi. Fungsi organisasi dan institusi lokal menurut Uphoff (1992); Cernea (1991, 1993); Curtis (1991); Norton (1992); IFAP (1992) adalah: (a) Mengatur sumberdaya (tenaga kerja) untuk menghasilkan produk lebih banyak; (b) Menggerakkan sumberdaya material untuk menolong produksi lebih banyak (kredit, tabungan, pemasaran); (c)Menolong beberapakelompokuntukmencapaiakses baru untuk sumberdaya produktif; (d) Mengamankan keberlanjutan dalam penggunaan sumberdaya alam; (e) Menyediakan infrastruktur sosial pada tingkat desa; (f) Mempengaruhi kebijakan institusi yang mempengaruhi mereka; (g) Menyediakan keterkaitan antara petani, peneliti dan pelayanan penyuluhan; (h) Meningkatkan akses populasi penduduk desa kepada informasi; (i) Meningkatkan aliran informasi dari pemerintah dan lembaga swadaya masyarakat; (j) Meningkatkan kohesi sosial; (k) Menyediakan kerangka kerja untuk kegiatan kerjasama; (1) Membantu mengatur masyarakat untuk menghasilkan dan menggunakan pengetahuan dan penelitian mereka untuk advokasi hak mereka; dan (m) Menjadi mediator untuk akses terhadap sumberdaya bagi kelompok terpilih.

Menurut Ostrom (1990) dan Rolling (1994), diacu dalam Pretty (1995), proses pembentukan kelompok mandiri pada tingkat lokal harus merupakan sebuah proses dalam masyarakat itu sendiri (organik) danharus tidak ditekan atau dikerjakan terlalu cepat. The International Federation of Agricultural ProceduresIFAP (1992) menyatakan ada empat elemen penting dalam mendukung penguatan organisasi petani, yaitu: (1) mengembangkan kemampuan keuangan (financiax) dengan sumberdaya yang telah dimiliki, terutama yang diperoleh secara langsung atau tidak langsung dari anggota kelompok; (2) pembentukan struktur pemilihan wakil petani; (3) memperoleh pengakuan sebagai legitimasi suara petani; dan (4) mengembangkan perencanaan mandiri, pengelolaan dan penyediaan pelayanan yang efektif

Kelembagaan berisikan dua aspek penting yaitu "aspek kelembagaan" dan "aspek keorganisasian". Aspek kelembagaan meliputi perilaku atau perilaku sosial, dimana inti kajiannya adalah tentang value, norm, custom, mores, folksway, usage, kepercayaan, moral, ide, gagasan, doktrin, keinginan, kebutuhan, orientasi dan lain-lain. Sementara dalam aspek keorganisasian meliputi struktur atau struktur sosial dengan inti kajiannya terletak pada aspek peran. Aspek keorganisasian difokuskan pada "struktur". Struktur dalam kelembagaan sangat penting karena menyediakan kejelasan tentang bagianbagian pekerjaan dalam aktivitas kelembagaan, bagaimana kaitan antar fungsi-fungsi yang berbeda, penjenjangan antar bagian, konfigurasi otoritas, kesalinghubungan antar otoritas, serta berhubungan dengan lingkungan sekitar. Struktur mencakup beberapa pemahaman sebagai berikut: (1) menggambarkan bagaimana hubungan antar bagian dalam lembaga secara keseluruhan; (2) tujuan; (3) peran dan kekterkaitan antar bagian; (4) keanggotaan; (5) kepemimpinan; dan (6) konflik.

Keberadaan kelembagaan internal masyarakat berpengaruh terhadap intensitas belajar petani dalam pengelolaan HRL. Intensitas belajar petani dalam pengelolaan hutan lestari sangat bergantung pada interaksi yang terjadi antara: (1) petani dengan fasilitator/penyuluh, (2) petani dengan petani lainnya; (3) petani dengan kelompok; (4) petani dengan materi belajar; dan (5) petani dengan lingkungan belajarnya. Intensitas belajar tinggi dihasilkan dari proses belajar yang interaktif akan memberdayakan peserta belajar, sebaliknya proses belajar yang "pasif" atau yang menempatkan peserta belajar sebagai obyek, bukan subyek dalam proses belajar akan menyebabkan petani yang tidak berdaya. Dalam intensitas belajar yang tinggi, frekuensi dan intensitas komunikasi banyak, komunikasi dilakukan dengan berbagai cara, serta manfaat adanya interaksi sangat mendukung proses belajar.

\section{Metode Penelitian}

Desain penelitian ini adalah survey, dan penelitian bersifat penelitian penjelasan ( $E_{X}$-planatory Research) yaitu menjelaskan hubungan kausalitas antara peubah-peubah penelitian. Lokasi penelitian ditentukan secara purposive yaitu di wilayah yang terdapat unit usaha Hutan Rakyat yang dikelola 
oleh masyarakat dan telah berhasil mendapatkan sertifikat Ekolabel. Populasi adalah petani pengelola Hutan Rakyat Lestari (sertifikasi) di Gunung Kidul dan Wonogiri. Teknik pengambilan sampel ialah dengan metode stratified random sampling dengan strata tingkat keaktivan dalam kelompok (pengurus dan bukan pengurus). Penentuan sampel penelitian menggunakan syarat minimal Structural Equation Models (SEM) yaitu 100-150 sampel. Wijanto (2008) dan Kusnendi (2008) menjelaskan bahwa penggunaan SEM dengan metode estimasi maximum likelihood memerlukan sampel sebanyak lima kali indikatorindikator (observed variables) yang ada dalam model, atau dapat ditetapkan dengan syarat minimal 100150 sampel. Jumlah keseluruhan responden dalam penelitian ini adalah 200 orang, yang tersebar di lima desa: dua desa di Kabupaten Wonogiri dan tiga desa di Kabupaten Gunung Kidul. Pengumpulan data primer dilakukan dengan menggunakan kuesioner, wawancara mendalam, dan observasi, sedangkan data sekunder diperoleh dari Dinas Kehutanan dan Perkebunan Kabupaten Gunung Kidul, Dinas Kehutanan dan Perkebunan Kabupaten Wonogiri, Badan Pelaksana Penyuluhan dan Ketahanan Pangan Kabupaten Gunung Kidul, dan Pusat Kajian Hutan Rakyat, Universitas Gadjah Mada. Pengolahan dan analisa data dilakukan dengan menggunakan statistik deskriptif menggunakan program SPSS 16.0, dan statistik inferensial Structural Equation Models (SEM), menggunakan program LISREL 8.70.

\section{Hasil dan Pembahasan}

\section{Hutan Rakyat di Gunung Kidul dan Wonogiri}

Hutan Rakyat di Gunung Kidul dan Wonogiri memiliki luasan yang cukup besar, dibandingkan dengan luasan hutan negara di wilayah tersebut. Luas hutan rakyat menurut Data Statistik Kabupaten Gunung Kidul (2009) adalah 30.000 hektar, tersebar di 18 kecamatan, sementara luasan hutan negara 8.560 hektar. Luas hutan rakyat di Wonogiri 36.293 hektar yang tersebar di 25 kecamatan, sedangkan hutan negara seluas 16.268 hektar. Dengan cakupan luasan tersebut, potensi hutan rakyat dapat dilihat dari volume kayu yang dihasilkan per tahun yang cukup tinggi, Gunung Kidul $122.460 \mathrm{~m}^{3}$ dan Wonogiri $264.159,1 \mathrm{~m}^{3}$.

Sejarah Hutan Rakyat di Gunung Kidul dan
Wonogiri menurut Awang dkk (2001) hampir sama. Sebagian besar lokasi penelitian di Gunung Kidul dan Wonogiri termasuk ke dalam Zona Pegunungan Seribu (Sewu) atau sering disebut Pegunungan Kapur Selatan. Sejarah Hutan Rakyat di Pegunungan Kapur Selatan menurut Awang dkk. (2001) dapat dibagi menjadi empat periode, yaitu (1) sebelum tahun 1960 periode kritis; (2) 1960-1970 periode penanaman mandiri; (3) 1970-1985 periode intensifikasi; dan (4) 1985-sekarang periode pemudaan alam. Sejak tahun 2002 hingga sekarang Hutan Rakyat berkembang pesat, Gerakan Nasional Rehabilitasi Hutan dan Lahan (GNRHL, yang sering disebut GERHAN), yang dicanangkan oleh Pemerintah, sejak 2002 telah meningkatkan luas Hutan Rakyat di daerah-daerah kritis seluas 1.102.912 hektar, termasuk di Gunung Kidul dan Wonogiri.

Sertifikasi Hutan Rakyat di Wonogiri dimulai pada tahun 2003, diawali dengan pengembangan kapasitas organisasi Hutan Rakyat melalui kerjasama dengan Perhimpunan untuk Studi dan Pengembangan Ekonomi dan juga Sosial (PERSEPSI), Lembaga Ekolabel Indonesia (LEI) dan World Wildlife Fund (WWF). Tujuan saat itu adalah pendampingan untuk mendapatkan sertifikasi Pengelolaan Hutan Bersama Masyarakat Lestari (PHBML) di Desa Selopuro dan Desa Sumberejo, Kecamatan Batuwarno. Sedangkan proses sertifikasi Hutan Rakyat di Gunung Kidul dimulai pada tahun 2004, diawali dengan program Rancang Bangun Unit Manajemen Hutan Rakyat Lestari (RBUMHRL) di 4 kabupaten, yaitu Gunung Kidul, Wonosobo, Magelang dan Purworejo. Kegiatan RBUMHRL di Gunung Kidul mencakup Desa Girisekar dan Desa Dengok, yang menjadi lokasi penelitian ini. Pada bulan Oktober 2004, Wonogiri mendapatkan sertifikat Ekolabel (PHBML) yang pertama dengan luas cakupan 809,95 hektar. Dua tahun kemudian menyusul Gunung Kidul mendapat sertifikat PHBML yaitu pada tanggal 20 September 2006 yang mencakup luasan 815,18 hektar.

\section{Kelembagaan Masyarakat}

Kelembagaan masyarakat berkaitan dengan hutan rakyat di Gunung Kidul dan Wonogiri, dari aspek kelembagaan tidak terlalu berbeda bentuknya, yaitu adanya aturan-aturan, nilai, kesepakatan dalam masyarakat berkaitan dengan pengelolaan hutan rakyat. Aturan-aturan tersebut ada yang tidak tertulis, 
Tabel 1 Perbandingan Penilaian terhadap Aspek-aspek Kelembagaan Masyarakat oleh Petani Hutan Rakyat Sertifikasi di Gunung Kidul dan Wonogiri

\begin{tabular}{|c|c|c|c|c|c|}
\hline \multirow{2}{*}{ No } & \multirow{2}{*}{ Aspek Kelembagaan Masyarakat } & \multirow{2}{*}{ Kategori } & \multicolumn{3}{|c|}{ Hutan Rakyat Lestari/sertifikasi (\%) } \\
\hline & & & Gunung Kidul & Wonogiri & Total \\
\hline \multirow[t]{4}{*}{1} & Kejelasan norma & Rendah & 31,0 & 41,0 & 36,0 \\
\hline & & Sedang & 44,0 & 44,0 & 44,0 \\
\hline & & Tinggi & 25,0 & 15,0 & 20,0 \\
\hline & Skor Rataan & & $60,1 a$ & $57,0 a$ & 58,5 \\
\hline \multirow[t]{4}{*}{2} & Penegakkan sanksi & Rendah & 36,0 & 73,0 & 54,5 \\
\hline & & Sedang & 35,0 & 23,0 & 29,0 \\
\hline & & Tinggi & 29,0 & 4,0 & 16,5 \\
\hline & Skor Rataan & & 55,6 & 33,7 & 44,6 \\
\hline \multirow[t]{4}{*}{3} & Konformitas & Rendah & 28,0 & 53,0 & 40,5 \\
\hline & & Sedang & 58,0 & 44,0 & 51,0 \\
\hline & & Tinggi & 14,0 & 3,0 & 8,5 \\
\hline & Skor Rataan & & 60,8 & 53,7 & 57,3 \\
\hline \multirow[t]{4}{*}{4} & & Rendah & 14,0 & 24,0 & 19,0 \\
\hline & Toleransi terhadap nilai baru & Sedang & 57,0 & 67,0 & 62,0 \\
\hline & & Tinggi & 29,0 & 9,0 & 19,0 \\
\hline & Skor Rataan & & 69,1 & 60,1 & 64,6 \\
\hline \multirow[t]{4}{*}{5} & Kesesuaian tujuan & Rendah & 16,0 & 34,0 & 25,0 \\
\hline & & Sedang & 51,0 & 40,0 & 45,5 \\
\hline & & Tinggi & 33,0 & 26,0 & 29,5 \\
\hline & Skor Rataan & & 66,8 & 59,7 & 63,2 \\
\hline \multirow[t]{4}{*}{6} & Kepemimpinan & Rendah & 5,0 & 12,0 & 8,5 \\
\hline & & Sedang & 29,0 & 41,0 & 35,0 \\
\hline & & Tinggi & 66,0 & 47,0 & 56,5 \\
\hline & Skor Rataan & & 79,9 & 73,4 & 76,7 \\
\hline \multirow[t]{4}{*}{7} & Keterkaitan antar bagian & Rendah & 9,0 & 19,0 & 14,0 \\
\hline & dalam kepengurusan & Sedang & 57,0 & 50,0 & 53,5 \\
\hline & & Tinggi & 34,0 & 31,0 & 32,5 \\
\hline & Skor Rataan & & 70,2 & 65,4 & 67,8 \\
\hline
\end{tabular}

Keterangan:

- $\mathrm{n}($ Gunung Kidul $)=100, \mathrm{n}($ Wonogiri $)=100, \mathrm{n}$ total $=200$;

- Skor Rataan: Rendah (0-50,0); Sedang (50,1-75,0); Tinggi (75,1-100)

- Angka yg diikuti oleh huruf yang sama tidak berbeda nyata pada taraf uji 0,05 (uji perbedaan nilai rataan $t$-test

namun telah dijalankan turun temurun sejak awal pengelolaan hutan rakyat misalnya aturan melakukan penanaman dan pemeliharaan pohon sampai hidup segera setelah melakukan penebangan. Di tiap lokasi penelitian ditemui aturan ini, baik tertulis maupun tidak tertulis, namun jumlah pohon yang ditanam bervariasi ada yang menetapkan 5 pohon, 10 pohon dan lainnya. Demikian juga dengan sanksi, ada sanksi yang tertulis maupun tidak tertulis namun terus diwariskan turun temurun seperti sanksi bagi masyarakat yang tidak melakukan penanaman setelah penebangan, biasanya sanksi ditetapkan dengan membayar denda. Namun baik di kedua lokasi sanksi ini tidak secara tegas dilaksanakan.

Sedangkan dari sisi organisasi yang berkaitan dengan hutan rakyat, di kedualokasi penelitian terdapat organisasi petani pengelola hutan rakyat. Keberadaan organisasi kelompok tani di Wonogiri relatif lebih 
Tabel 2 Intensitas Belajar Petani Hutan Rakyat Lestari (Sertifikasi) di Gunung Kidul dan Wonogiri

\begin{tabular}{|c|c|c|c|c|c|}
\hline \multirow[b]{2}{*}{ No } & \multirow[b]{2}{*}{ Aspek intensitas pembelajaran } & \multirow[b]{2}{*}{ Kategori } & \multicolumn{3}{|c|}{ Hutan Rakyat Lestari (\%) } \\
\hline & & & $\begin{array}{c}\text { Gunung } \\
\text { Kidul }\end{array}$ & Wonogiri & Total \\
\hline \multirow[t]{4}{*}{1} & Interaksi petani dengan penyuluh & Rendah & 32,0 & 84,0 & 58,0 \\
\hline & & Sedang & 58,0 & 14,0 & 36,0 \\
\hline & & Tinggi & 10,0 & 2,0 & 6,0 \\
\hline & Skor Rataan & & 52,4 & 26,8 & 39,6 \\
\hline \multirow[t]{4}{*}{2} & Interaksi petani dengan petani & Rendah & 10,0 & 18,0 & 14,0 \\
\hline & & Sedang & 69,0 & 74,0 & 71,5 \\
\hline & & Tinggi & 21,0 & 8,0 & 14,5 \\
\hline & Skor Rataan & & 64,9 & 57,0 & 61,0 \\
\hline \multirow[t]{4}{*}{3} & Interaksi petani dengan kelompok tani & Rendah & 13,0 & 27,0 & 20,0 \\
\hline & & Sedang & 75,0 & 70,0 & 72,5 \\
\hline & & Tinggi & 12,0 & 3,0 & 7,5 \\
\hline & Skor Rataan & & 57,2 & 48,7 & 53,0 \\
\hline \multirow[t]{4}{*}{4} & Interaksi petani dengan materi pembelajaran & Rendah & 33,0 & 84,0 & 58,5 \\
\hline & & Sedang & 59,0 & 15,0 & 37,0 \\
\hline & & Tinggi & 8,0 & 1,0 & 4,5 \\
\hline & Skor Rataan & & 51,4 & 24,2 & 37,8 \\
\hline \multirow[t]{4}{*}{5} & Interaksi petani dengan lingkungan belajar & Rendah & 34,0 & 60,0 & 47,0 \\
\hline & & Sedang & 57,0 & 40,0 & 48,5 \\
\hline & & Tinggi & 9,0 & 0,0 & 4,5 \\
\hline & Skor Rataan & & 49,4 & 37,7 & 43,6 \\
\hline
\end{tabular}

Keterangan:

- $\mathrm{n}($ Gunung Kidul $)=100, \mathrm{n}($ Wonogiri $)=100, \mathrm{n}$ total $=200$;

- Skor Rataan: Rendah (0-50,0); Sedang (50,1-75,0); Tinggi

(75,1-100)

lama, yaitu dibentuk tahun 1970-an, bersamaan dengan pengembangan hutan rakyat secara swadaya. Misalnya, Kelompok Tani Percabaan di Dusun Pagersengon, Desa Selopuro, Kecamatan Batuwarno, Wonogiri merupakan kelompok tani pelopor gerakan penanaman tanaman kayu-kayuan secara swadaya di Desa Selopuro. Kelompok tersebut dibentuk karena kesadaran masyarakat dan adanya kebutuhan untuk kegiatan bergotong royong mengatasi permasalahan kekeringan di Desa Selopuro. Sejak awal dibentuk pada tahun 1970-an sampai dengan saat ini Kelompok Tani Percabaan ini masih berjalan dengan baik.

Berbeda dengan kelompok tani di Wonogiri yang relatif lebih lama, sebagian kelompok tani di Gunung Kidul baru dibentuk dan didampingi terutama berkaitan dengan penguatan kelompok melalui program Rancang Bangun Unit Manajemen Hutan
Rakyat Lestari (RBUMHRL), contohnya kelompok tani di Desa Dengok, Kec. Playen dan Desa Giri Sekar, Kec. Panggang yang dibentuk pada tahun 2004. Sedangkan di Desa Kedungkeris, kelompok tani lebih relatif lebih lama dibentuk yaitu pada tahun 1990-an dan sampai dengan penelitian dilakukan, pertemuanpertemuan kelompok masih terus berjalan. Sebagai contoh Kelompok Tani Hutan Rakyat (KTHR) Ngudi Makmur yang dibentuk pada tahun 1996, masih tetap melakukan pertemuan kelompok yaitu setiap Senin Legi, walaupun pertemuan lebih difokuskan pada kegiatan arisan simpan pinjam.

Organisasi kelompok tani di kedua lokasi penelitian dibentuk dengan pola organisasi modern, namun belum dapat dijalankan layaknya sebuah organisasi modern. Kelompok tani sudah memiliki aturan tertulis Anggaran Dasar/Anggaran Rumah Tangga 


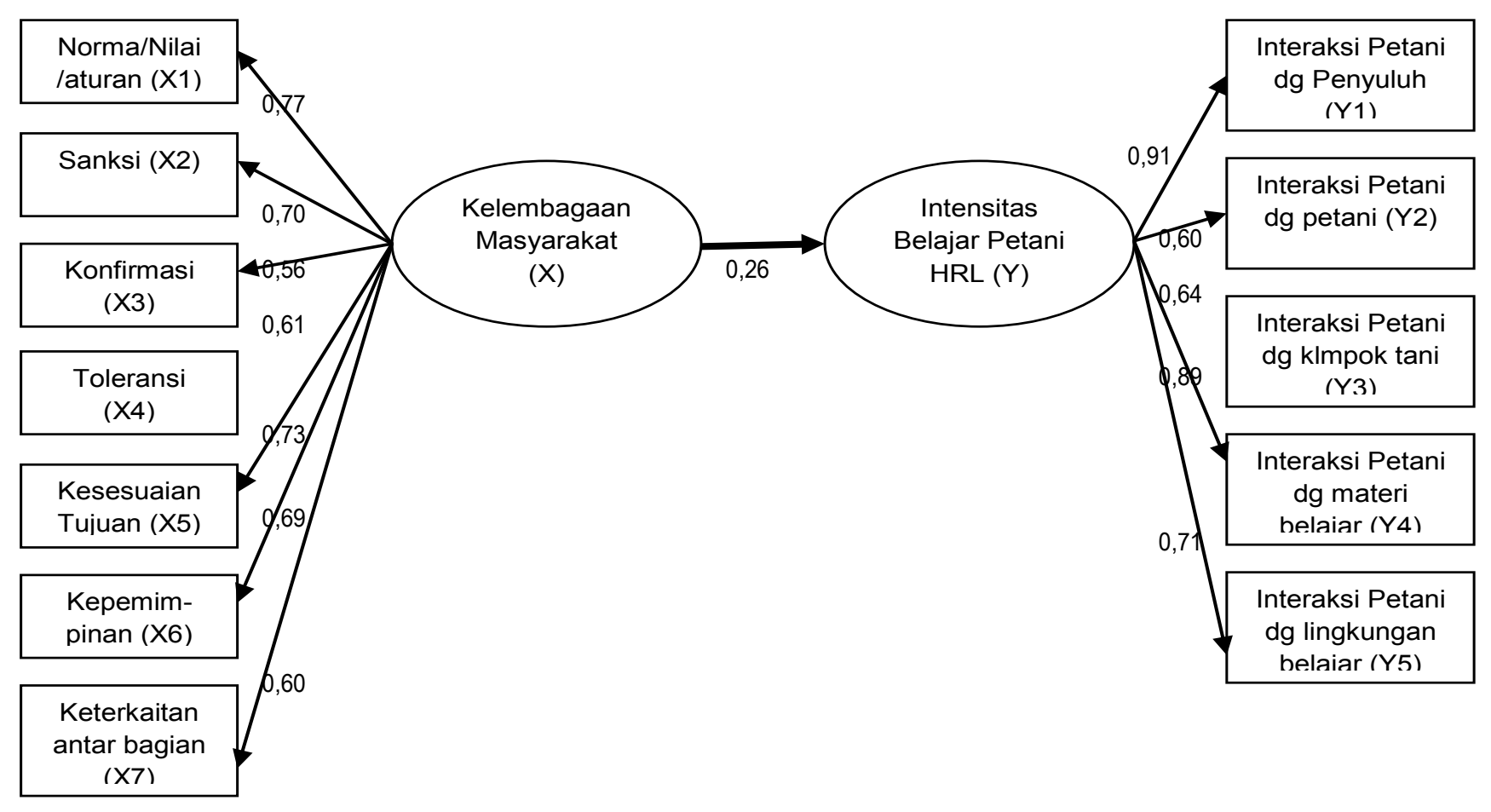

Chi-Square $=340,15, d f=347, P$-value $=0,05934, R M S E A=0.073, C F I=0,98$

Gambar 2 Hubungan Antar Variabel Penelitian

(AD/ART), sudah ada pembagian tugas, namun belum dijalankan dengan benar. Dari segi kepemimpinan, hampir semua ketua kelompok tani Hutan Rakyat di kedua lokasi penelitian adalah tokoh masyarakat seperti kepala Dusun dan ketua RT/RW.

Selain organisasi yang dibentuk secara internal oleh masyarakat karena kebutuhan dan keinginan mereka sendiri, terdapat juga organisasi yang dibentuk secara eksternal oleh pihak LSM atau Perguruan Tinggi untuk memenuhi persyaratan sertifikasi hutan rakyat. Sebagai contoh di Wonogiri dibentuk organisasi baru yaitu Forum Komunitas Petani Sertifikasi (FKPS), yang merupakan gabungan dari kelompok-kelompok tani hutan rakyat yang ada di tiap dusun. Pembentukan organisasi atau kelompok oleh pihak luar, yang tidak benar-benar berdasarkan kebutuhan masyarakat setempat, dan tanpa didahului oleh proses penyadaran masyarakat, sehingga akhirnya tidak berjalan sesuai dengan yang diharapkan. Sekalipun FKPS ini telah memiliki visi dan misi tertulis dan sangat jelas.

Demikian halnya di Gunung Kidul, dibentuk Gabungan Kelompok Manunggal Lestari, yang mewadahi kelompok-kelompok tani hutan rakyat yang ada di dusun-dusun dan desa di wilayah tersebut. Berkaitan dengan pemasaran dan lainnya, di Gunung Kidul juga dibentuk Koperasi Wana Manunggal Lestari dengan Akte Notaris No.31 tanggal 21 September 2006. Keanggotaan koperasi ini adalah semua anggota kelompok tani secara otomatis menjadi anggota. Untuk memperlancar koordinasi dengan ketiga desa, maka kepengurusan koperasi ditetapkan dengan melibatkan tokoh atau pengurus dari tiga desa sebagai perwakilan.

Masyarakat di Gunung Kidul dan Wonogiri menilai lembaga yang dibentuk secara internal, baik lembaga informal seperti halnya arisan, gotong royong, kelompok pengajian/yasinan, maupun lembaga formal seperti Kelompok Tani atau KTHR, paling berpengaruh dalam pembelajaran masyarakat tentang hutan rakyat lestari. Sedangkan lembaga formal yang dibentuk secara eksternal seperti FKPS, Paguyuban Kelompok Tani dan Koperasi belum berperan sebagaimana mereka kehendaki. Kondisi ini sejalan dengan pendapat Ostrom (1990) dan Rolling (1994), diacu dalam Pretty (1995), bahwa proses pembentukan kelompok mandiri pada tingkat lokal harus merupakan sebuah proses dalam 
masyarakat itu sendiri (organik) dan harus tidak ditekan atau dikerjakan terlalu cepat.

Penilaian dari para responden terhadap aspek kelembagaan masyarakat di kedua lokasi penelitian tergolong sedang (Tabel 1). Aspek tertinggi yang dinilai baik oleh masyarakat di kedua lokasi penelitian ialah kepemimpinan, sedangkan yang terendah ialah penegakkan sanksi. Aspek kepemimpinan dalam penilaiankelembagaan masyarakatbaikdi Gunung Kidul maupun Wonogiri dinilai tinggi oleh petani sertifikasi dalam mendukung pembelajaran Hutan Rakyat Lestari. Salah satu alasan mendasar ialah sebagian besar pengurus kelompok tani adalah tokoh masyarakat dan aparat yang dipercaya dan menjadi panutan masyarakat. Dengan demikian pemimpin kelompok, yang juga menjadi pemimpin di masyarakat sangat mendukung dan menjadi bagian dalam pembelajaran dan pengembangan Hutan Rakyat Lestari di masyarakat tersebut. Sanksi, yang dikenakan kepada setiap pelanggaran, bukan saja kurang ditegakkan dengan baik, tetapi juga kurang dipahami oleh masyarakat. Sanksi-sanksi tersebut baik di Gunung Kidul maupun Wonogiri umumnya tidak tertulis dan kurang disosialisasikan dalam masyarakat, sehingga tidak dapat diwariskan secara turun temurun dan akhirnya menghilang. Oleh karenanya penilaian terhadap penegakan sanksi di kedua lokasi penelitian adalah rendah.

\section{Kejelasan Norma}

Kejelasan norma dalam hal ini termasuk nilainilai yang diyakini masyarakat, aturan-aturan tertulis maupun tidak tertulis berkaitan dengan pengelolaan hutan rakyat lestari. Sebagai contoh aturan tentang kewajibanmelakukanpenanaman setelah penebangan, kepercayaan kepada pemimpin/ pemerintah, gotong royong/sambatan, dan nilai hidup/budaya kerja keras. Penilaian responden terhadap kejelasan norma, baik di Gunung Kidul maupun di Wonogiri termasuk dalam kategori sedang. Beberapa aturan tersebut bahkan kemudian dijadikan aturan tertulis di kelompok tani. Bahkan beberapa kelompok tani telah memiliki AD/ART, misalnya Paguyuban Pengelola Hutan Rakyat (PPHR) Ngudi Lestari di Desa Dengok yang dibentuk pada tanggal 18 Desember 2004. PPHR Ngudi Lestari telah menyusun aturan internal pada dua kali pertemuan dan telah disahkan pada tanggal 28 Januari 2005. Aturan internal itu antara lain adalah aturan keuangan simpan pinjam.

\section{Penegakkan Sanksi}

Penegakkan sanksi pada suatu pelanggaran terhadap aturan yang telah disepakati bersama, di Gunung Kidul tergolong sedang, sedangkan di Wonogiri tergolong rendah. Sebagian besar petani di Wonogiri menyatakan tidak mengetahui adanya sanksi terhadap suatu pelanggaran dalam pengelolaan hutan rakyat. Ketidaktahuan masyarakat tersebut dapat disebabkan beberapa alasan, di antaranya adalah karena kurangnya sosialisasi, atau karena kurang ditegakkannya sanksi tersebut, sehingga lama kelamaan 'luntur' tergerus oleh waktu, sekalipun sanksi tersebut merupakan aturan yang telah diwariskan turun-temurun. Sebagai contoh di Wonogiri, khususnya di Dusun Pagersengon, ada sanksi tidak tertulis, yang telah berlaku sejak awal pembentukan kelompok tani. Misalnya ialah bagi anggota kelompok tani yang menebang pohon sebelum mencapai umur tertentu, yaitu berupa keharusan menanam 60 bibit tanaman keras dan memeliharanya sampai tumbuh.

\section{Konformitas}

Tingkat konformitas petani sertifikasi/ Hutan Rakyat Lestari di kedua lokasi penelitian tergolong sedang. Masyarakat petani pengelola hutan rakyat, baik di Gunung Kidul maupun Wonogiri masih memegang aturan-aturan atau nilai-nilai tradisi yang berlaku dalam kehidupan bermasyarakat. Misalnya sambatan, yaitu gotong royong dalam membersihkan lahan untuk penanaman, membangun rumah, rukun jagong, bersih desa dan lainnya. Kegiatan sosial ini tetap terus dijaga sebagai pengikat kohesivitas anggota kemasyarakatan. Walaupun tergolong desa yang cukup maju, masyarakat di kedua lokasi penelitian masih menjaga nilai-nilai budaya masyarakat, dan tetap sedia mematuhi aturan-aturan atau nilai-nilai yang telah diwarisi turun temurun.

\section{Toleransi}

Tingkat toleransi masyarakat di kedua lokasi penelitian tergolong sedang. Masyarakat di Gunung Kidul dan Wonogiri walaupun memiliki tingkat konformitas yang cukup tinggi, namunjuga cukupmudah menerima nilai-nilai baru, khususnya yang membawa kemajuan untuk mereka. Masyarakat Gunung Kidul menilai bahwa segala program Pemerintah pasti baik 
untuk mereka sehingga mereka dengan mudah dapat menerima segala bentuk campur tangan Pemerintah, termasuk yang berkaitan dengan pengembangan hutan rakyat. Sebaliknya mereka juga dapat mengurangi atau menghapuskan secara perlahan-lahan kebiasaankebiasaan turun temurun yang dinilai kurang baik oleh masyarakat sendiri.

\section{Kesesuaian Tujuan}

di kedua lokasi penelitian menilai "sedang" pencapaian tujuan organisasi kelompok tani sampai dengan saat ini. Keberadaan kelompok tani saat ini lebih sebagai wadah untuk arisan, pertemuan rutin tetap berjalan tetapi tidak lagi sesuai dengan tujuan pembentukkannya yaitu menjadi wadah pembelajaran, pembahasan permasalahan yang dihadapi petani dan lainnya. Kelompok tani yang ada, khususnya di Wonogiri, tidak lagi mendapatkan pendampingan atau pembinaan dari Pemerintah maupun LSM. Dengan demikian tujuan kelompok tani, visi dan misi yang telah ditetapkan dan dituangkan dalam AD/ART organisasi tidak lagi diperjuangkan bersama untuk pencapaiannya.

\section{Kepemimpinan}

Penilaian kepemimpinan dalam organisasi atau kelompok pengelola hutan rakyat di kedua lokasi penelitian berbeda. Masyarakat di Gunung Kidul menilai kepemimpinan "tinggi", sementara masyarakat di Wonogiri menilai kepemimpinan "sedang". Masyarakat Gunung Kidul cukup puas dengan kepemimpinan dalam kelompok tani sampai dengan saat ini. Sementara di Wonogiri adanya ketidakpuasan terhadap kepemimpinan lebih cenderung kepada kepemimpinan FKPS, bukan terhadap kepemimpinan Kelompok Tani, sehingga penilaian terhadap kepemimpinan kelompok tani masih dinilai sedang (cukup baik).

\section{Keterkaitan antar Bagian}

Baik di Gunung Kidul maupun Wonogiri, telah tersusun kepengurusan Kelompok Tani dengan pembagian tugas yang cukup jelas. Minimal terdiri dari Ketua, Sekretaris dan Bendahara, sementara keberadaan bagian lain berbeda antara kelompok yang satu dengan lainnya, disesuaikan dengan kondisi dan kebutuhan masyarakat setempat. Struktur organisasi berikut susunan nama pengurus di lima kelompok tani (dari sepuluh kelompok tani dalam penelitian) terpampang di sekretariat kelompok, yang sebagian besar adalah tempat tinggal ketua kelompok. Lima kelompok tani lainnya yang diteliti, tidak memiliki papan struktur organisasi tetapi susunan kepengurusan semua terdapat di dalam AD/ ART. Walaupun sudah ada pembagian tugas yang sangat jelas, namun belum ada keterkaitan dalam melaksanakan tugas pengelolaan hutan rakyat.

\section{Intensitas Belajar Petani}

Secara keseluruhan intensitas belajar petani Hutan Rakyat Lestari di kedua lokasi rendah (Tabel 2). Terdapat perbedaan nyata antara intensitas belajarpetani Hutan Rakyat Lestari di Gunung Kidul dan Wonogiri. Semua indikator intensitas belajar di Gunung Kidul tergolong sedang, sedangkan di Wonogiri tergolong rendah. Interaksi petani dengan petani di kedua lokasi paling tinggi, yang mengindikasikan petani sertifikasi, baik di Gunung Kidul maupun Wonogiri masih lebih banyak memanfaatkan pembelajaran melalui sesama petani. Sedangkan interaksi petani dengan materi belajar paling rendah, hal ini berkaitan dengan rendahnya para petani memanfaatkan sumber-sumber materi pembelajaran di luar apa yang didapatkan dari penyuluh melaui pertemuan kelompok. Bila dikaitkan dengan tipe pembelajaran menurut Dwiyogo (2001), pembelajaran petani di kedua lokasi tersebut belum mengarah ke pembelajaran visioner, dimana pembelajaran dapat dilakukan dimana saja, kapan saja, dengan siapa saja, melalui apa saja. Artinya pembelajaran tidak tergantung pada suatu tempat, pada suatu waktu tertentu dengan sumber belajar yang tidak terbatas pada guru, dalam hal ini penyuluh/ pendamping.

\section{Interaksi antara Penyuluh dengan Petani}

Interaksi dari para petani dengan penyuluh atau pendamping di kedua lokasi tergolong rendah. Tetapi bila diperbandingkan antara kedua lokasi tersebut terdapat perbedaan nyata, yaitu di Gunung Kidul tergolong sedang sedangkan di Wonogiri tergolong rendah. Sebagian besar petani $(63,3 \%)$ di Wonogiri sangat jarang bertemu dengan penyuluh atau pendamping, bahkan beberapa orang menyebutkan sampai dengan penelitian ini dilakukan belum pernah bertemu dengan penyuluh 
atau pendamping.

Berbeda dengan daerah Wonogiri, di Gunung Kidul frekuensi petani bertemu dengan penyuluh dan pendamping lebih sering, terutama pada saat pendampingan sertifikasi HR dan juga sebelumnya pada program rancang bangun unit manajemen $\mathrm{HR}$ (RBUMHR). Pertemuan dengan penyuluh atau pendamping terutama pada kegiatan pertemuan kelompok atau diskusi lainnya berkaitan dengan sertifikasi atau RBUMHR, khususnya untuk Desa Girisekar dan Desa Dengok yang didampingi oleh LSM Shorea dan Arupa untuk RBUMHR. Untuk Desa Kedungkeris frekuensi lebih banyak dan hubungan lebih akrab karena pendamping yang berasal dari PKHR telah mendampingi secara rutin dari tahun 2000 terus sampai saat penelitian dilakukan. Namun diakui oleh petani HRL di Gunung Kidul, karena pertemuan dengan pendamping atau penyuluh lebih sering dalam pertemuan formal sehingga hubungannya akrab namun seperti masih ada 'jarak'. Hal ini sejalan dengan pendapat Flander (1969), diacu dalam Klausmeier dan Goodwin (1971) yang menyebutkan bahwa interaksi guru dan murid sangat dipengaruhi oleh hubungan interpersonal, komunikasi verbal dan non verbal. Interaksi guru dan murid terjadi jika ada komunikasi dua arah dan seimbang.

\section{Interaksi Petani dengan Petani}

Interaksi petani dengan petani (Tabel 2) di kedua lokasi tergolong sedang. Hubungan yang baik antar petani, baik untuk permasalahan umum maupun yang berkaitan dengan pengelolaan usahatani, ditunjang oleh masih kuatnya hubungan persaudaraan pada masyarakat Gunung Kidul dan Wonogiri. Hubungan persaudaraan masyarakat di Gunung Kidul dan Wonogiri masih cukup baik, dibuktikan dengan masih berjalannya dan kentalnya budaya "sambatan", jagong dan lainnya. Juga berkaitan dengan pengalaman saat-saat sulit menghadapi kondisi lahan yang tandus, kekeringan dan kelaparan, kemudian berjuang bersama hingga mencapai kondisi lingkungan yang baik, dan perekonomian yang lebih baik. Interaksi yang baik antar petani, dan masih kentalnya hubungan persaudaraan membuat situasi yang aman dalam berusahatani, tidak ada konflik berkaitan dengan batas lahan, hampir tidak ada kasus pencurian di ladang, saling menghormati dan ikut menjaga lahan usaha tetangganya dengan menjaga jarak tanam di perbatasan lahannya.

\section{Interaksi antara Petani dan Kelompok Tani}

Terdapat perbedaan nyata antara interaksi petani dengan kelompok tani di kedua lokasi. Petani di Gunung Kidul menilai interaksi dengan Kelompok Tani tergolong sedang, sedangkan petani di Wonogiri menilai rendah. Beberapa hal yang dapat menjelaskan perbedaan tersebut antara lain ialah pendampingan kelompok tani di Gunung Kidul pada saat penelitian dilakukanmasihterusberjalan, sekalipuntelahdiperoleh sertifikasi. Sehingga pertemuan kelompok masih terus berjalan, walaupun sebagian besar lebih difokuskan pada arisan. Sedangkan di Wonogiri ada permasalahan dan kekecewaan anggota terhadap kepengurusan, terutama Forum Komunitas Petani Sertifikasi (FKPS) yang sampai dengan penelitian ini dilakukan, belum ada upaya untuk menyelesaikannya. Hal ini sejalan dengan pendapat Flander (1969), diacu dalam Klausmeier dan Goodwin (1971) yang menyebutkan bahwa interaksi sesama murid, akan mendukung pencapaian tujuan kelompok. Kekohesivan kelompok sangat berperan dalam mendukung proses belajar.

\section{Interaksi antara Petani dengan Materi Pembelajaran}

Petani dengan materi belajar di kedua lokasi berbeda nyata, di Gunung Kidul tergolong sedang, sedangkan di Wonogiri tergolong rendah. Adanya perbeda-an yang cukup mencolok ini berkaitan erat dengan keberadaan Kelompok Tani di Wonogiri yang sudah tidak terlalu aktif menjadi tempat pembelajaran petani HRL. Interaksi petani dengan materi belajar di Gunung Kidul cukup baik, walaupun kesempatan berinteraksi tersebut tidak merata karena lebih banyak kesempatan yang diperoleh pengurus kelompok tani dan tokoh masyarakat. Berkaitan dengan HRL, materi belajar yang didapatkan petani ialah pemetaan partisipatif, inventarisasi tegakan pohon, dan perencanaan pengelolaan HR. Sebagian besar materi merupakan 'given' dari lembaga pendukung pendampingan. Namun pada beberapa kelompok di Gunung Kidul, terdapat beberapa materi yang sesuai dengan kebutuhan dan keinginan petani, misalnya pelatihan/magang pembuatan furniture.

Kondisi tersebut telah menunjukkan bahwa interaksi petani dan materi pembelajaran di kedua 
lokasi masih terbatas pada pertemuan kelompok dan penyuluh/pendamping sebagai sumber materi, dimana materi "given" kurang sesuai kebutuhan. Hal ini belum mencapai apa yang diharapkan dengan pembelajaran orang dewasa yang dikembangkan oleh Knowles (1980), Jarvis (1985), yang menekankan pada pembelajaran pada pemecahan permasalahan dan materi sesuai dengan kebutuhan petani sehingga dapat membantu petani menyelesaikan permasalahnnya.

\section{Interaksi Petani dengan Lingkungan Belajar}

Interaksi petani dengan lingkungan belajar di kedua lokasi tergolong rendah. Petani sedikit memiliki akses untuk berinteraksi dengan lingkungan belajar, yang berkaitan dengan pengelolaan hutan rakyat lestari. Lingkungan belajar dalam hal ini hal-hal yang mendukung proses belajar HRL, baik sarana prasarana, institusi yang mendukung proses belajar dan lainnya. Di Gunung Kidul sebenarnya sudah ada sarana pembelajaran untuk mengelola pemasaran HRL yaitu Koperasi Wana Manunggal Lestari yang mewadahi petani sertifikasi di Gunung Kidul, tetapi aksesnya sangat terbatas, karena letaknya di desa yang berbeda kecamatan, sehingga sulit bagi petani dari desa lainnya untuk menjangkaunya. Akses bagi anggota terhadap pihak-pihak yang berkaitan dengan pembelajaran Hutan Rakyat Lestari, juga sangat sulit dijangkau. Tegalan, pekarangan tempat mereka mengelola lahan adalah lingkungan belajar yang baik, mudah dijangkau oleh semua petani, tetapi seringkali tidak disadari oleh petani, sehingga memerlukan pendampingan agar petani dapat menyadari, memanfaatkannya dalam pembelajaran hutan rakyat lestari.

\section{Pengaruh Kelembagaan Masyarakat Terhadap Intensitas Belajar Petani}

Hasil dari analisa SEM menunjukkan bahwa kelembagaan masyarakat berpengaruh nyata terhadap intensitas belajar petani Hutan Rakyat Lestari (Gambar 1). Lembaga informal dalam masyarakat seperti arisan, sampai dengan saat ini berjalan baik di kedua lokasi penelitian. Lembaga ini berlangsung cukup lama dan cukup diminati oleh warga. Petani sertifikasi/Hutan Rakyat Lestari di kedua lokasi penelitian mengakui bahwa arisan menjadi lembaga yang mempunyai peranan dalam pembelajaran petani. Wadah ini bila ditinjau dari segi ekonomi/keuangan tidak terlalu besar manfaatnya, karena mereka hanya mengumpulkan Rp. 1000-2000/bulan. Tetapi wadah ini menjadi daya tarik bagi petani untuk berkumpul, bersosialisasi dan saling tukar menukar informasi dan hiburan petani setelah seharian bekerja di ladang.

Organisasi formal lainnya yang berkaitan dengan pembelajaran HRL seperti Kelompok Tani, Gabungan Kelompok Tani, FKPS (di Wonogiri), Koperasi Wana Manunggal Lestari (di Gunung Kidul) dan lainnya diakui juga berperan, tetapi sebagian besar petani mengakui bahwa peranan organisasi formal tersebut dalam pembelajaran petani berada di urutan setelah arisan. Artinya organisasi formal tersebut belum dapat sepenuhnya berperan sebagai wadah pembelajaran yang paling efektif bagi petani HRL di kedua lokasi penelitian. Dari hasil analisa SEM (Gambar 1), diperoleh hasil bahwa aspek kelembagaaan masyarakat yang berpotensi mempengaruhi intensitas belajar petani adalah norma/nilai, kemudian diikuti dengan adanya kesamaan tujuan, dan kepemimpinan. Norma atau nilai-nilai yang diyakini dan dijalankan oleh masyarakat di Gunung Kidul dan Wonogiri memberikan pengaruh yang baik terhadap intensitas belajar petani HRL. Beberapa contoh nilai-nilai dalam masyarakat yang mendukung intensitas belajar petani HRL ialah kepercayaan kepada pemimpin/pemerintah, aturan tentang kewajiban melakukan penanaman setelah penebangan, gotong royong/sambatan, dan nilai hidup/budaya kerja keras.

Petani HRL di Gunung Kidul sangat mempercayai pemerintah dan pemimpinnya. Hal ini terbukti, ketika sertifikasi HRL belum menampakkan hasil yang diharapkan yaitu kenaikan harga jual kayu (premium price) mereka mengaku kecewa tetapi tidak mempersalahkan pemimpin atau pemerintah yang telah mengenalkan dan membawa mereka untuk memperoleh sertifikasi HRL. Mereka tetap percaya bahwa pemerintah selalu berniat baik untuk memajukan masyarakatnya. Kepercayaan masyarakat Gunung Kidul terhadap pemerintah merupakan kapital sosial yang potensial dalam pengembangan pembelajaran HRL di Gunung Kidul. Hal ini ditegaskan oleh Fukuyama (1995), yang diacu dalam Field (2010). Menurut Fukuyama kepercayaan adalah unsur dasar kapital sosial. Kapital sosial adalah kapabilitas yang muncul dari kepercayaan abadi di tengah-tengah masyarakat atau pada bagian tertentu dari masyarakat tersebut. Kepercayaan adalah dasar dari tatanan sosial, komunitas bergantung pada kepercayaan timbal balik 
dan tidak akan muncul secara spontan. Selanjutnya Field (2010) menegaskan bahwa jaringan dengan kepercayaan tinggi akan berfungsi lebih baik dan lebih mudah daripada dalam jaringan dengan kepercayaan rendah. Hal ini terbukti di Forum Komunitas Petani Sertifikasi(FKPS) di Wonogiri, jaringan tidak berfungsi dengan baik karena petani tidak mempercayai pengurus FKPS.

Adanya norma atau aturan-aturan tidak tertulis berkaitan dengan HRL, yang masih dipegang oleh masyarakat dan diwariskan secara turun temurun di kedua lokasi penelitian. Misalnya kewajiban menanam, dan memelihara pohon yang ditanam, tidak lama setelah menebang di lahannya. Wajib tanam berbeda dalam hal jumlahnya, baik antar dusun maupun antar kabupaten. Norma ini bahkan di beberapa kelompok sudah menjadi aturan tertulis yang dituangkan dalam AD/ ART Kelompok tani. Norma dan aturan tidak tertulis, baik di Gunung Kidul dan Wonogiri, juga merupakan kapital sosial, yang tidak dapat dipisahkan dengan jaringan dan kepercayaan. Menurut Fukuyama (1999), yang diacu oleh Field (2010), norma muncul dari pertukaran yang saling menguntungkan secara berulang-ulang.

Budaya gotong royong juga mempermudah proses pembelajaran HRL. Salah satu aspek dalam HRL ialah aspek sosial, sehingga tidak sulit bagi masyarakat untuk mempelajari dan memiliki sikap positif terhadap HRL ditinjau dari aspek sosial. Walaupun dalam penerapannya, masih sulit bagi masyarakat untuk bekerja sama dan masih banyak mengembangkan HRL secara individual. Masyarakat masih belum terbiasa berorganisasi secara formal, sehingga sulit bagi masyarakat untuk dapat mengelola kelompok tani sebagai kelompok formal. Apalagi bila kelompok itu memang sengaja dibentuk oleh lembaga eksternal pendukung pembelajaran untuk memenuhi persyaratan mendapatkan sertifikat ekolabel tanpa adanya kesadaran dan kebutuhan masyarakat untuk membentuknya. Sebagai contoh, salah satu kelompok tani di Desa Girisekar yaitu Kelompok Sekar Eko Jati, yang pada saat penelitian dilakukan sudah "mati", karena memang kelompok ini dibentuk pada pertengahan proses sertifikasi di Gunung Kidul tanpa adanya sosialisasi dan pendekatan, hanya untuk memenuhi persyaratan luasan HRL.

Sebaliknya pada Kelompok Tani Percobaan di Wonogiri, yang memang tumbuh pada tahun 1970-an secara swadaya karena kebutuhan masyarakat sendiri, yang pada saat itu sedang giat-giatnya bergotong royong melakukan penanaman di dusun Jarak. Sampai dengan saat ini kelompok tersebut masih berjalan dengan baik, walaupun memang belum dapat mengikuti dinamika organisasi modern seperti yang diharapkan, dengan adanya pembagian tugas yang baik dan keterkaitan antar bagian dalam menjalankan organisasi.

Arisan dan gotong royong yang berkembang baik di kedua lokasi penelitian, yang didasarkan oleh persahabatan, keke-rabatan dan kepercayaan merupakan kapital sosial yang perlu terus dipertahankan dan dikembangkan. Hubungan sosial pada masyarakat ini menjadi kekuatan yang sangat mendukung proses pembelajaran HRL, dan bila terus dilestarikan dapat membentuk kapital lainnya, kapital manusia, kapital fisik dan lainnya. Dengan kapital sosial, kapital manusia dan kapital fisik yang berasal dari masyarakat sendiri akan sangat mendukung keberlanjutan pengelolaan HRL. Lawang (2005) menegaskan bahwa bila semua kapital yang tersedia di dalam masyarakat (manusia, fisik dan sosial) dimanfaatkan seoptimal mungkin dalam suatu program, maka bukan saja mencapai tujuan yang diinginkan tetapi juga menghasilkan keberlanjutan program itu sendiri.

Nilai-nilai hidup/budaya kerja keras, yang sangat kental terlihat di kedua lokasi penelitian, juga mempengaruhi pembelajaran petani HRL. Kesulitan hidup di waktu yang lampau karena kondisi fisik lahan dan alam yang sangat kritis telah menempa dan membentuk sikap mental penduduk di Gunung Kidul dan Wonogiri sebagai pekerja keras. Tidak jarang pada saat penelitian ditemui orang-orang yang sudah lanjut usia masih bekerja di ladang, bahkan membawa pakan ternak dalam jumlah yang sangat banyak. Tidak jarang para wanita setengah baya memanen hasil ladang dan membawanya untuk dijual di pasar dengan berjalan kaki berkilo meter. Mereka tetap melakukan pekerjaan-pekerjaan berat sekalipun secara finansial kebutuhan mereka telah terpenuhi karena ditunjang oleh anak-anak mereka yang telah berhasil dalam pekerjaan di kota-kota besar, bahkan luar negeri.

Kesesuaian tujuan organisasi kemasyarakatan dengan tujuan anggota, merupakan aspek kelembagaan masyarakat yang berpotensi mempengaruhi intensitas belajar petani HRL. Kesesuaian tujuan ini penting bagi kelangsungan organisasi dan partisipasi anggota dalam mempertahankan organisasi tersebut. Bila kesesuaian tujuan ini tidak tercapai, organisasi tersebut 
cenderung akan sulit berkembang, bahkan seringkali "mati". Pada penelitian ini ditemukan beberapa bukti yang menguatkan pernyataan ini. Berkaitan dengan persyaratan sertifikasi HRL, dibentuk-lah Koperasi Wana Manunggal Lestari (KWML) di Gunung Kidul, Forum Komuni-tas Petani Sertifikasi (FKPS) dan Tempat Pengelolaan Kayu Sertifikasi (TPKS) di Wonogiri, serta kelompok tani di beberapa desa yang memang belum ada kelompok tani, seperti di Dusun Belimbing, Desa Girisekar, Gunung Kidul. Organisasiorganisasi tersebut dibentuk lebih kepada kepentingan perolehan sertifikat tanpa didahului dengan proses penyadaran, sosialisasi dan pembentukan kesepahaman mengenai visi, misi dan tujuan organisasi, sehingga akhirnya masyarakat tidak merasa bahwa dirinya sebagai bagian dari organisasi dan merasa perlu untuk mempertahankan dan mengembangkan organisasi tersebut. Oleh karenanya maka kelangsungan dan dinamika kelompok atau organisasi tersebut perlahanlahan memudar, kritis bahkan mati. Hal ini sejalan dengan pendapat Cartwright dan Zander (1968) tentang dinamika kelompok, bahwa salah satu ciri dinamika kelompok adalah kesesuaian tujuan organisasi dengan tujuan anggota kelompok. Salah satu ciri kelompok yang dinamis ialah jika ada kesesuaian tujuan kelompok dengan tujuan anggota.

Aspek kepemimpinan merupakan aspek kelembagaan masyarakat yang cukup potensial mempengaruhi intensitas belajar petani HRL. Kepemimpinan di kedua lokasi penelitian cukup berpengaruh untuk kelangsungan dan dinamika kelompok tani. Sebagian besar ketua kelompok HRL adalah kepala dusun, yang merupakan kepercayaan masyarakat dan menjadi panutan masyarakat. Dengan demikian segi positif dari ketua kelompok yang merangkap kepala dusun ialah dinamika kelompok cukup terjaga, apalagi dengan kepala dusun yang juga menjadi ketua Gapoktan ataupun Ketua Tani Nasional Andalan. Kelompok yang dikepalai oleh tokohtokoh ini relatif lebih maju, karena luasnya jaringan informasi maupun anggaran yang dapat diakses oleh ketua memberi dampak positif bukan saja pada dusun tetapi juga kepada kelompok tani yang dipimpinnya. Hal ini sejalan dengan pendapat Djogo (2005) bahwa kepemimpinan menjadi andalan dalam upaya pembangunan berkelanjutan. Bila dikaitkan dengan pendapat Schermerhorn et al., (1997) tentang bentuk kepemimpinan, yaitu kepemimpinan formal dan informal, maka di kedua lokasi penelitian, khususnya ketua kelompok tani tergolong kempimpinan formal dan sekaligus informal. Karena ketua kelompok selain ditunjuk atau dipilih dalam posisi tertentu oleh otoritas formal dari organisasi; juga memiliki kemampuan yang dibutuhkan untuk dapat mempengaruhi orang lain.

\section{Peningkatan Peran Kelembagaan Masyarakat dalam Intensitas Belajar Petani}

Peningkatan intensitas belajar petani, yang saat ini secara umum di kedua lokasi tergolong sedang, dapat dilakukan juga dengan menguatkan kelembagaan yang ada dalam masyarakat berkaitan dengan penge-lolaan HRL. Kelembagaan masyarakat yang ada saat ini di Gunung Kidul dan Wonogiri cenderung tergolong sedang, baik ditinjau dari sisi norma atau aturan maupun dari sisi organisasi. Dari hasil analisa SEM, asspek kelembagaan masyarakat yang berpotensi mempengaruhi intensitas belajar petani ialah norma/nilai/aturan, sanksi dan kesesuaian tujuan. Dengan demikian untuk meningkatkan intensitas belajar perlu penguatan kelembagaan masyarakat terutama pada aspek norma/ nilai/aturan; sanksi dan kesesuaian tujuan.

Norma, aturan atau nilai-nilai yang berlaku dalam kelompok atau organisasi formal dan informal dalam masyarakat seperti kepercayaan kepada pemimpin atau pemerintah, nilai kerja keras, gotong royong atau sambatan merupakan kapital sosial, perlu terus dipelihara dan dikembangkan menjadi kekuatan potensial dalam pembangunan kehutanan berkelanjutan, khususnya HRL. Kapital sosial ini perlu terus dipelihara dan dikembangkan karena kapital sosial seperti kapital yang lain, dapat meningkat dan menurun bahkan menghilang. Kapital sosial merupakan kekuatan yang tidak terlihat yang dapat mendorong keberhasilan partisipasi masyarakat. Hasil penelitian Putnam di Italia menggambarkan adanya korelasi positif antara kapital sosial dan kinerja Pemerintah Daerah. Kapital sosial mempunyai peranan penting dalam penciptaan pemerintah daerah yang responsif dan efisien, yang ditandai dengan adanya masyarakat yang kuat dan dinamis (Sumardjo, 2010). Tiga komponen inti kapital sosial yang perlu menjadi komitmen penyuluh menurut Sumardjo (2010) ialah: (1) kemampuan membangun kelembagaan; (2) adanya partisipasi yang setara dan adil, dan (3) adanya sikap saling percaya, saling mendukung, saling peduli 
sehingga saling memperkuat di antara pihak yang terlibat dalam jaringan.

Semua kelompok tani Hutan Rakyat Lestari di kedua lokasi penelitian telah memiliki aturan tidak tertulis dan aturan tertulis, dalam AD/ART berkaitan dengan pengelolaan HRL. Tetapi sebagian besar petani tidak memahami aturan-aturan tersebut, ataupun lupa ketika ditanyakan dalam wawancara. Hal tersebut membuktikan bahwa aturan-aturan ini masih bersifat sangat formal, dan belum "melekat" dalam kehidupan berkelompok atau bermasyarakat. Memang dalam penyusunan aturan ini hanya beberapa orang pengurus saja yang terlibat, dan cenderung lebih banyak peran pendamping. Dan setelah aturan dibuat, tidak disosialisasikan dalam pertemuanpertemuan kelompok sehingga sebagian besar petani HRL tidak memahami aturan tersebut. Oleh karena itu untuk peningkatan intensitas pembelajaran petani, maka aturan dan norma kelompok perlu dibuat bersama sesuai dengan kebutuhan dan permasalahan nyata yang dihadapi oleh petani HRL, dan sering disosialisasikan dalam pertemuan-pertemuan atau kegiatan kelompok lainnya.

Penerapan sanksi, baik bagi petani Wonogiri dan Gunung Kidul sulit dilakukan dan hampir tidak dilakukan dalam kehidupan bermasyarakat dan berkelompok. Sebenarnya sanksi mempunyai fungsi yang sama pentingnya dengan aturan atau norma kelompok. Peningkatan intensitas pembelajaran petani HRL ke depan diharapkan dapat lebih tegas menjalankan sanksi, sesuai dengan apa yang telah disepakati bersama. Oleh karena itu perlu juga ditetapkan dan disepakati bersama beberapa orang yang dipercaya dan ditunjuk sebagai pengawas penegakkan sanksi oleh anggota kelompok/masyarakat untuk menjaga dan mengembangkan pengelolaan HRL yang lebih baik.

Kesesuaian antara tujuan organisasi/kelompok dengan tujuan petani Hutan Rakyat Lestari menjadi indikator yang cukup kuat merefleksikan kelembagaan masyarakat. Perlu diakui bahwa banyak kelompok atau organisasi masyarakat yang dibentuk lebih cenderung untuk kepentingan pihak luar dalam rangka pemenuhan persyaratan sertifikasi, bukan atas dasar kebutuhan petani HRL. Sehingga banyak tujuan organisasi atau kelompok yang kurang sesuai dengan tujuan anggota kelompok, bahkan anggota tidak memahami tujuan dirinya terlibat dalam kelompok atau organisasi tersebut. Hal ini menyebabkan dinamika kelompok dalam organisasi atau kelompok tidak berjalan baik. Sebagai contoh kepercayaan masyarakat terhadap koperasi di Gunung Kidul masih belum cukup baik, ketidakpercayaan dan kekurangpahaman petani Hutan Rakyat Lestari tentang tujuan, fungsi dan tugas FKPS di Wonogiri menyebabkan organisasi yang sebenarnya sangat penting bagi pengembangan HRL tersebut tidak berjalan dengan baik, bahkan untuk FKPS dapat dikatakan "mati".

Untuk peningkatan intensitas belajar petani perlu dipikirkan pembentukan dan pengembangan bentuk organisasi atau kelompok yang sesuai dengan kebutuhan dan sesuai dengan sosial budaya masyarakat sehingga dapat tumbuh dan berakar dalam masyarakat. Sebenarnya, di kedua lokasi penelitian terdapat kelompok-kelompok arisan yang sangat efektif dan diminati oleh petani sebagai wadah pembelajaran para petani. Sebaiknya kelompok-kelompok yang telah ada dalam masyarakat seperti kelompok arisan, pengajian, dan lainnya yang dapat dikuatkan sebagai wadah pembelajaran petani. Saat ini pembentukan kelompok masih cenderung mengikuti pola modern, yang kurang dipahami dan kurang sesuai dengan budaya masyarakat sehingga tidak dapat berjalan dengan baik.

Koperasi, kelompok tani yang merupakan wadah bagi petani pengelola HRL perlu ditingkatkan kapasitasnya, khususnya berkaitan dengan pemasaran dan manajemen. Dengan peningkatan kapasitas tersebut diharapkan petani mempunyai posisi tawar yang lebih baik, dan dan mengelola HRL secara mandiri. Hal ini sejalan dengan hasil penelitian Liu dan Yuan (2007) bahwa diperlukan reformasi kelembagaan untuk pengembangan kehutanan skala kecil di Cina dengan pengembangan asosiasi pengelola hutan skala kecil, dengan memberikan pelatihan teknis dan pemasaran. Capill (2000) juga menegaskan bahwa salah satu faktor kesuksesan usahatani kehutanan di New Zealand adalah adanya organisasi otonom petani hutan yang meningkatkan kapasitas anggota, khususnya dalam membuat keputusan manajemen hutan yang rasional.

\section{Kesimpulan}

Kelembagaan masyarakat yang berperan dalam pembelajaran petani sertifikasi/ Hutan Rakyat Lestari di Gunung Kidul dan Wonogiri adalah kelembagaan formal dan kelembagaan informal. Kelembagaan informal internal masyarakat, seperti aturan yang konsisten berkaitan pengelolaan Hutan Rakyat Lestari, arisan, 
nilai-nilai lokal seperti kepercayaan pada pemimpin, gotong royong, budaya kerja keras dan lainnya berperan penting di Gunung Kidul dan Wonogiri. Sedangkan kelembagaan formal eksternal, yang dibentuk oleh pihak luar dan kurang mengakar di masyarakat, tidak sesuai dengan kebutuhan masyarakat, serta lebih difokuskan pada pemenuhan persyaratan sertifikasi saja, seperti Koperasi, Kelompok Tani, Forum Komunitas Petani Sertifikasi, tidak dapat berjalan dengan baik. Peran kelembagaan masyarakat informal lebih besar dibandingkan kelembagaan formal dalam pembelajaran petani sertifikasi.

Kelembagaan masyarakat secara langsung berpengaruh nyata terhadap intensitas belajar petani di Gunung Kidul dan Wonogiri. Aspek kelembagaan masyarakat yang ber-potensi mempengaruhi intensitas belajar petani, terutama adalah: norma/nilai/aturan, kesesuaian tujuan dan kepemimpinan. Adanya norma/ aturan/ nilai yang mendukung seperti adanya aturan tentang penanaman kembali, pelarangan penebangan pohon dengan diametertertentu, budayagotong royong dan lainnya meningkatkan intensitas belajar petani. Kesesuaian tujuan organisasi atau kelompok dengan kebutuhan masyarakat menyebabkan intensitas belajar petani lebih baik. Kepemimpinan kelompok yang merangkap aparat desa, memberikan pengaruh dalam memotivasi petani dalam pembelajaran Hutan Rakyat Lestari.

Peningkatan peran kelembagaan masyarakat dalam intensitas belajar petani ialah melalui penguatan lembaga informal seperti arisan, kelompok yasinan dan lainnya menjadi wadah pembelajaran petani, perumusan kembali norma atau aturan berikut sanksi yang sesuai dan realistis untuk dijalankan demi pengembangan HRL. Untuk meingkatkan peranan kelembagaan formal yang penting dalam pembelajaran Hutan Rakyat Lestari seperti kelompok tani, koperasi dan lainnya dibutuhkan peningkatan kapasitas petani dalam manajemen kelompok dan organisasi.

\section{Daftar Pustaka}

Awang SA, Santoso H, Widayanti WT, Nugroho Y. 2001. Gurat Hutan Rakyat di Kapur Selatan. Yogyakarta: CV Debut Press.

Cartwright D dan Zander A. 1968. Group Dynamics: Research and Theory. Ed ke-3. New York: Harper and Row Publishers.
Cernea MM, editor. 1988. Mengutamakan Manusia Di Dalam Pembangunan. Jakarta: UI Press

Darusman. 1995. Hutan Rakyat: Pengembangan Strategis Kehutanan dalam Pembenahan Kehutanan Indonesia, Dokumentasi Kronologi Tulisan 1986-2002. Bogor: Laboratorium Politik Ekonomi dan Sosial dan Yayasan Dani Hanifah.

Djogo T. 2005. Kepemimpinan Lingkungan: Kelembagaan, Kekuasaan dan Konstituen dalam Urgensi Kepemimpinan dalam Pembangunan Berkelanjutan. Di dalam: Indonesian Journal for Sustainable Future 1:1-28.

Dwiyogo DW. 2008. Pembelajaran Visioner. Malang: Wineka Media.

Field J. 2010. Modal Sosial. Yogyakarta: Kreasi Wacana.

Jarvis P. 1985. The Sociology of Adult and Continuing Education. London: Croom Helm.

Klausmeier HJ, Goodwin W. 1971. Learning and Human Abilites: Educational Pschology. Fourth Ed. New York: Harper \& Row Publisher.

Knowles M. 1979. The Adult Learner: A Neglected Species. Second Edition. Texas: Gulf Publishing Company.

Koentjaraningrat. 1992. Kebudayaan Mentalitas dan Pembangunan. Jakarta: Gramedia Pustaka Utama.

Lawang RMZ. 2005. Kapital Sosial dalam Perspektif Sosiologik. Jakarta: FISIP UI Press.

Mindawati N, Widiarti A, Rustaman B. 2006. Review Hasil Penelitian Hutan Rakyat. Bogor: Badan Litbang Kehutanan.

Pretty JN, Roling N. 1997. Extension's Role in Sustainable Agricultural Development. Di dalam : Improving Agricultural Extension A Reference Manual. Editor: Swanson BE, Bentz RP, Sofranko AJ. Rome : Food and Agriculture Organization of The United Nations.

Pretty JN. 1995. Regenerating Agriculture: Policies and Practise for Sustainability and Self-Reliance. London: Earthscan Publications Ltd.

Reed AS. 2004. Strategic Relationships: Engaging for Cooperation, Collaboration and Partnerships. Di dalam Proceedings of IUFRO Forestry Extension Conference, 28 September-2 October 2003, Troutdale, Oregon USAH. 2003.

Schermerhorn JR, Hunt JG, Osborn RN. 1997. Organizational Behavior. Ed.ke-6. New York: 
Jurnal Penyuluhan, September 2012 Vol. 9 No. 2

John Willey and Sons, Inc.

Seng OT et.al. 2001. Educational Psychology. Singapore: Seng Lee Press.

Soemanto WS. 2006. Psikologi Pendidikan. Jakarta:

Rineka Cipta
Sudjana SHD. 2000. Strategi Pembelajaran. Bandung: Falah Production

Sumardjo. 2010. Penyuluhan Menuju Pengembangan Kapital Manusia dan Kapital Sosial dalam Mewujudkan Kesejahteraan Rakyat. Orasi ilmiah Guru Besar IPB. Bogor: IPB Press. 